\title{
Extended Release Fiber Dosage Form
}

National Cancer Institute

\section{Source}

National Cancer Institute. Extended Release Fiber Dosage Form. NCI Thesaurus. Code C60926.

A solid in the shape of a slender, elongated thread that is designed to release active and/or inert ing redient(s) at a controlled, prolonged rate so as to reduce dosing frequency. 